\title{
ANATOLIAN STUDIES
}

Journal of the British Institute of Archaeology at Ankara

Votive Reliefs from Balboura and its Environs, by Tyler Jo Smith, with an Epigraphical Appendix by N. P. Milner

A paramone Text on a Family Funerary bomos at Burdur Museum, by G. H. R. Horsley and R. A. Kearsley - $\quad$ - $\quad$ - $\quad$ - $\quad$ - $\quad$ - $\quad$ - $\quad$ - 51

The Alacami in Kadirli: Transformations of a Sacred Monument, by Richard Bayliss -

The Shaft Monuments and the taurobolium among the Phrygians, by Vecihi

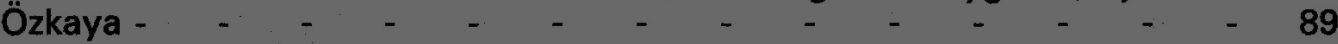

Muş in the Early Bronze Age, by Mitchell S. Rothman and Gülriz Kolbe $\quad$ - 105

The Annals of Hattusilis III, by O. R. Gurney - $\quad$ - $\quad$ - $\quad$ - $\quad$ - $\quad$ - 127

The Pisidian Survey 1995: Panemoteichos and Ören Tepe, by Sabri Aydal, Stephen Mitchell, Thurstan Robinson and Lutgarde Vandeput - - - 141

Early Bronze Age Plant Remains from Imamoğlu Höyük, South-east Turkey, by E. Oybak and Ş. Demirci - - - $\quad-\quad-\quad-\quad-173$

Beycesultan 1954: some Byzantine Remains, by G. R. H. Wright - - - - 177

Das Edikt des L. Antistius Rusticus: eine Preisregulierung als Antwort auf eine überregionale Versorgungskrise, by Hans-Ulrich Wiemer - - 195

Nearchus the Cretan and the Foundation of Cretopolis, by Nicholas Victor Sekunda

List of Abbreviations

Published annually by

THE BRITISH INSTITUTE OF ARCHAEOLOGY AT ANKARA Senate House, Malet Street, London WC1E 7HU 
ANATOLIAN STUDIES is a refereed journal.

Notes for contributors were appended in Vol. XLVI.

Articles for publication and other correspondence should be addressed to The Editor, Anatolian Studies,

B.I.A.A., Senate House, Malet Street, London WC1E 7HU 


\section{ANATOLIAN STUDIES}

\section{CONTENTS}

Page

Votive Reliefs from Balboura and its Environs, by Tyler Jo Smith, with an Epigraphical Appendix by N. P. Milner

A paramone Text on a Family Funerary bomos at Burdur Museum, by G. H. R. Horsley and R. A. Kearsley

The Alacami in Kadirli: Transformations of a Sacred Monument, by Richard Bayliss -

The Shaft Monuments and the taurobolium among the Phrygians, by Vecihi Özkaya -

Muş in the Early Bronze Age, by Mitchell S. Rothman and Gülriz Kolbe - 105

The Annals of Hattusilis III, by O. R. Gurney - $\quad$ - $\quad$ - $\quad$ - $\quad$ - $\quad$ - $\quad$ - 127

The Pisidian Survey 1995: Panemoteichos and Ören Tepe, by Sabri Aydal, Stephen Mitchell, Thurstan Robinson and Lutgarde Vandeput -

Early Bronze Age Plant Remains from Imamoğlu Höyük, South-east Turkey, by E. Oybak and Ş. Demirci - $\quad$ - $\quad$ - $\quad$ - $\quad$ - $\quad$ - $\quad$ - $\quad$ - 173

Beycesultan 1954: some Byzantine Remains, by G. R. H. Wright - _ - 177

Das Edikt des L. Antistius Rusticus: eine Preisregulierung als Antwort auf eine überregionale Versorgungskrise, by Hans-Ulrich Wiemer - 195

Nearchus the Cretan and the Foundation of Cretopolis, by Nicholas Victor Sekunda

List of Abbreviations

Published annually by

THE BRITISH INSTITUTE OF ARCHAEOLOGY AT ANKARA Senate House, Malet Street, London WC1E 7HU 